\title{
COAL MINING AND PREPARATION IN SERBIA
}

Milena Kostović ${ }^{1}$, Nebojša Kostović ${ }^{2}$ and Rade Tokalić ${ }^{1}$

Received: September 8, 2018

Accepted: October 16, 2018

\begin{abstract}
Coal reserves in Serbia represent an important strategic energy raw materials on which in the coming decades will be based energy development in Serbia. Coal mining in Serbia is performed by surface, underground and underwater mining, and within each of them there are also the coal preparation facilities. Underground mining is done in the scope of the JP PEU Resavica, which includes eight active mines: Bogovina, Rembas, Vrška čuka, Štavalj, Ibar, Soko, Jasenovac and Lubnica. Surface mining is carried out as part of a JP EPS. Mining operation is done in mining basin Kolubara and Kostalac which are supplier of three thermal power plants: Kolubara, Nikola Tesla and Morava. Underwater mining and preparation of coals in Serbia has been done in Kovin coal mine. Coal production, processes of preparation and quality for all active mines in Serbia are presented in this review paper.
\end{abstract}

Keywords: coal; mining; mines; preparation; thermal power plants; Serbia;

\section{INTRODUCTION}

The first coal mine was opened in Vrdnik on Fruška gora in 1804. This year presents the beginning of Serbian mining and preparation. In 1836 the first national coal mine was opened in village Mliva near Despotovac. In 1846 the first private coal mine Dobra on Danube was opened. At the end of XIX century, Serbia have had 20 opened coal mines. Coal production has been increasing permanently, so before World War II production was $7 \times 10^{6} \mathrm{t} / \mathrm{y}$. After the war, coal production in Yugoslavia was increasing until 60's, when oil began to suppress the use of coal and it comes to closing a number of mines. After the 1973, coal has become the primary fossil fuel. Then intensive building of thermal power plants started near open pit mines, where the largest coal reserves are located (Nikolić, 1990).

\section{Genesis of coal in Serbia}

For the coal genesis in Serbia several geological periods are important. At the end of the Triassic and early Jurassic (Liassic) a number of occurrences and deposits of hard coal were formed (Vrška Čuka, Dobra sreća, Ibar). During the Upper Cretaceous, Tertiary-

\footnotetext{
${ }^{1}$ University of Belgrade - Faculty of Mining and Geolgy

${ }^{2}$ Mining institute, Belgrade

Emails: milena.kostovic@rgf.bg.ac.rs; $\underline{\text { rade.tokalic@ rgf.bg.ac.rs; }}$ pms@ ribeograd.ac.rs
} 
Neogene, Oligocene and Miocene significant deposits of brown coal and some deposits of hard coal were formed (Bogovina, Soko banja, Aleksinac). In the Pliocene a great deposits of lignite, Kolubara and Kostolac, were formed (Nikolić, 1990).

\section{Classification of coal in Serbia}

In Serbian literature and practice there is a genetic classification of coal including several types of coal: hard coal or anthracite, brown coal and lignite. Hard coal is called hard coal because of some properties although it has a high sulphur content (4-8\%) and high ash content (18-27\%). Therefore, their utilization is limited to thermal purposes. Brown coal also has a high ash content (12-35\%) and relatively high sulphur content (0.9-3.8\%). Lignite is characterized by high moisture content (34-56\%), ash content of 9-21\% and sulphur content of $0.5-1 \%$ and often above $1 \%$. All coals except for some brown coal, have a relatively small low calorific value (Nikolić, 1990, Vuletić, 2004).

\section{UNDERGROUND MINING AND PREPARATION OF COALS IN SERBIA}

Underground mining is done in the scope of the Public Enterprise for Underground Coal Mining (JP PEU) Resavica, which includes eight active mines: Bogovina, Rembas, Vrška čuka, Štavalj, Ibar, Soko, Jasenovac and Lubnica. Preparation of brown coals are done in Bogovina, Rembas, Štavalj, Soko and Jasenovac mines. Preparation of lignite is done in Lubnica mine. Preparation of hard coal is done in Ibar mine and preparation of anthracite is done in Vrška čuka mine. The annual production of coals of different quality is about $500.000-600.000 \mathrm{t} / \mathrm{y}$. JP PEU produces coal mostly for commercial users and also for power plants (Ivković, 2012).

JP PEU employs about 4.021 employees (JPPEU, 2017).

In Bogovina mine coal is prepared on next way: run-of-mine coal is screened on feeder wobber (opening of $60 \mathrm{~mm}$ ) and, in next stage, on $8 \mathrm{~mm}$ vibratory screen. Size class $8+0 \mathrm{~mm}$ presents final product - clean coal for combustion in thermal power plants, while size class $-60+8 \mathrm{~mm}$ is treated in autogeneous suspension by Parnaby process. Products of cleaning are: $-60+30 \mathrm{~mm}$ and $-30+0.5 \mathrm{~mm}$ clean coals, tailings (size class $-60+0 \mathrm{~mm}$ ) and refuse slurry. Also, hand sorting of clean coal from oversize $+60 \mathrm{~mm}$ is included.

In Rembas mine coal is comminuted by crushing to $100 \%-150 \mathrm{~mm}$, and then coal is screened on two screens (with openings $15 \mathrm{~mm}$ and $8 \mathrm{~mm}$ ), when clean coals $-15+8 \mathrm{~mm}$ and $-8+0 \mathrm{~mm}$ are obtained as final products. The undersize of first screen, size class $150+15 \mathrm{~mm}$, is sent to wet cleaning in a suspension of magnetite in dense medium drumtype separator Wemco. The products are: clean coal, middlings and tailings. Clean coal and middlings are being screened on $+60 \mathrm{~mm},-60+30 \mathrm{~mm}$ and $-30+8$ size classes as final products of clean coal. 
In Vrška Čuka mine technological process of cleaning coal consists of the following stages: the run-of-mine coal, size class $-150+0 \mathrm{~mm}$, after dry screening and crushing to $100 \%-30 \mathrm{~mm}$, is sent to wet cleaning in dense-medium separator Bassambre with magnetite as suspensoid. The products are: clean coal $-30+0.5 \mathrm{~mm}$, which is shipped to consumers, tailings $-30+0.5 \mathrm{~mm}$, which is send to tailings dump and refuse slurry -0.5 $\mathrm{mm}$, which also has marketing and sales to brick kilns.

The preparation of coal in Štavalj coal mine is performed in two plants: one plant is for dry classification and the second plant is so-called Parnaby plant. In the classification plant, the run-of-mine coal, size class $-250+0 \mathrm{~mm}$, is screened on $60 \mathrm{~mm}$ screen on two size classes, $+60 \mathrm{~mm}$ and $-60+0 \mathrm{~mm}$. Clean coal $+60 \mathrm{~mm}$ is hand sorted from screen undersize. Screen oversize $-60+0 \mathrm{~mm}$ is sent to cleaning in autogeneous suspension in Parnaby plant. Cleaning products are obtained as follows: clean coal $-60+0 \mathrm{~mm}$, tailings $-60 \mathrm{~mm}$ and refuse slurry $-0.25 \mathrm{~mm}$. Clean coal $-60+0 \mathrm{~mm}$ is screened on next size classes $-60+30 \mathrm{~mm},-30+15 \mathrm{~mm},-15+0.25 \mathrm{~mm}$ as final products.

The technological process of coal preparation in Ibar mine is carried out in two different cleaning circuits: the coarse coal circuit $(-150+10 \mathrm{~mm})$ and the fine coal circuit $(-10+0$ $\mathrm{mm})$. Coarse size class $-150+10 \mathrm{~mm}$ is cleaned in Drew-boy concentrator in two stages, in suspension of magnetite (at density of $1.6 \mathrm{~kg} / \mathrm{dm}^{3}$ and $1.95 \mathrm{~kg} / \mathrm{dm}^{3}$ ). The obtained $150+10 \mathrm{~mm}$ clean coal is crushed and screened on commercial classes, while middlings and tailings cleaned together in next Drew-boy concentrator. The floating product of the second concentrator after crushing and screening is treated together with fine size class. The fine size class $-10+0 \mathrm{~mm}$ after desliming on $0.5 \mathrm{~mm}$ screen is cleaned in two stages in Turpinson devices (on density $1.7-1.8 \mathrm{~kg} / \mathrm{dm}^{3}$ and $2.1 \mathrm{~kg} / \mathrm{dm}^{3}$ ). Obtained clean coal and middlings are sent to thermal power plants on combustion.

The technological process of preparation in Soko coal mine is performed similarly as in mines Bogovina and Štavalj. Cleaning process is performed in autogeneous suspension by Parnaby process. Run-of-mine coal, size class $-250+0 \mathrm{~mm}$, screened on several size classes on rollen rost (openings of $60 \mathrm{~mm}$ ) and double-deck screen (openings of $30 \mathrm{~mm}$ and $15 \mathrm{~mm}$ ). Size classes $-30+15 \mathrm{~mm}$ and $-15+0 \mathrm{~mm}$ are sent to Parnaby plant on cleaning. Beside clean coal, $-30+15 \mathrm{~mm}$ and $-15+0 \mathrm{~mm}$, Soko mine produced clean coal $+60 \mathrm{~mm}$ and $-60+30 \mathrm{~mm}$.

The technological process of coal preparation in the coal mine Jasenovac is performed in simple stages: hand sorting and dry screening on screens with perforated plates with openings of 60, 20 and $10 \mathrm{~mm}$. In this way, clean coal products are following: $+60 \mathrm{~mm}$, $-60+20 \mathrm{~mm},-20+10 \mathrm{~mm}$ and $-10+0 \mathrm{~mm}$.

The preparation of coal in Lubnica lignite mine is performed similar like in mine Jasenovac. The technological process includes dry screening of run-of-mine coal on rollen rost and screens. On this way, clean coal products, size classes $-30+15 \mathrm{~mm}$ and - 
$15+0 \mathrm{~mm}$ were obtained. In addition to these, clean coals, size classes $-250+60 \mathrm{~mm}$ and $-60+30 \mathrm{~mm}$, were obtained by hand sorting in preparation plant.

Table 1 shows the production of coal in underground coal mines in Serbia and quality of raw coals (Kostović, 2011).

Table 1 Production of coal in underground coal mines in Serbia and quality of raw coal

\begin{tabular}{lrcccc}
\hline \multicolumn{1}{c}{ Mine } & $\begin{array}{c}\text { Mass, } \\
\mathrm{t}\end{array}$ & $\begin{array}{c}\text { Moisture, } \\
\%\end{array}$ & $\begin{array}{c}\text { Ash, } \\
\%\end{array}$ & $\begin{array}{c}\mathrm{Ash}_{\text {w.m. }}, \\
\%\end{array}$ & $\begin{array}{c}\text { L.C.V., } \\
\text { GJ } / \mathrm{t}\end{array}$ \\
\hline Bogovina & 67167 & 26.00 & 34.85 & 47.09 & 8.67 \\
Rembas & 216534 & 12.90 & 40.40 & 46.39 & 11.00 \\
Vrška Čuka & 18946 & 1.90 & 28.83 & 29.39 & 21.90 \\
Štavalj & 98339 & 30.47 & 22.19 & 31.92 & 10.13 \\
Ibar & 68021 & 6.00 & 57.80 & 61.48 & 10.50 \\
Soko & 95774 & 21.26 & 21.11 & 26.80 & 14.80 \\
Jasenovac & 74000 & 22.36 & 28.53 & 36.75 & 11.71 \\
Lubnica & 54643 & 30.72 & 23.55 & 33.99 & 11.06 \\
\hline
\end{tabular}

Table 2 shows the quality of clean coal for various size classes in underground coal mines in Serbia (Kostović, 2011).

Table 2 Quality of clean coal for various size classes in underground coal mines in Serbia

\begin{tabular}{lcccc}
\hline $\begin{array}{c}\text { Products } \\
\text { (size classes) }\end{array}$ & $\begin{array}{c}\text { Moisture, } \\
\%\end{array}$ & $\begin{array}{c}\text { Ash, } \\
\%\end{array}$ & $\begin{array}{c}\text { Ash }_{\text {w.m. }}, \\
\%\end{array}$ & $\begin{array}{c}\text { L.C.V., } \\
\text { GJ/t }\end{array}$ \\
\hline$+60 \mathrm{~mm}$ & $20.14-26.00$ & $7.11-12.69$ & $8.52-15.89$ & $13.50-20.75$ \\
$-60+30(20) \mathrm{mm}$ & $6.00-32.70$ & $8.41-27.00$ & $9.91-28.72$ & $12.85-22.50$ \\
$-30(20)+15(10) \mathrm{mm}$ & $7.00-32.00$ & $11.70-28.00$ & $17.51-40.11$ & $9.85-21.50$ \\
$-30+8 \mathrm{~mm}$ & $15.10-29.60$ & $14.12-16.78$ & $16.62-23.84$ & $13.75-18.53$ \\
$-10(8)+0 \mathrm{~mm}$ & $23.70-26.60$ & $21.78-22.18$ & $28.15-30.63$ & $11.57-12.56$ \\
$-15(10)+0.25(0) \mathrm{mm}$ & $8.00-33.00$ & $13.00-37.00$ & $19.40-50.41$ & $8.20-22.50$ \\
\hline
\end{tabular}

Figure 1 shows the flowsheet of coal cleaning in autogeneous suspension in Parnaby plant 


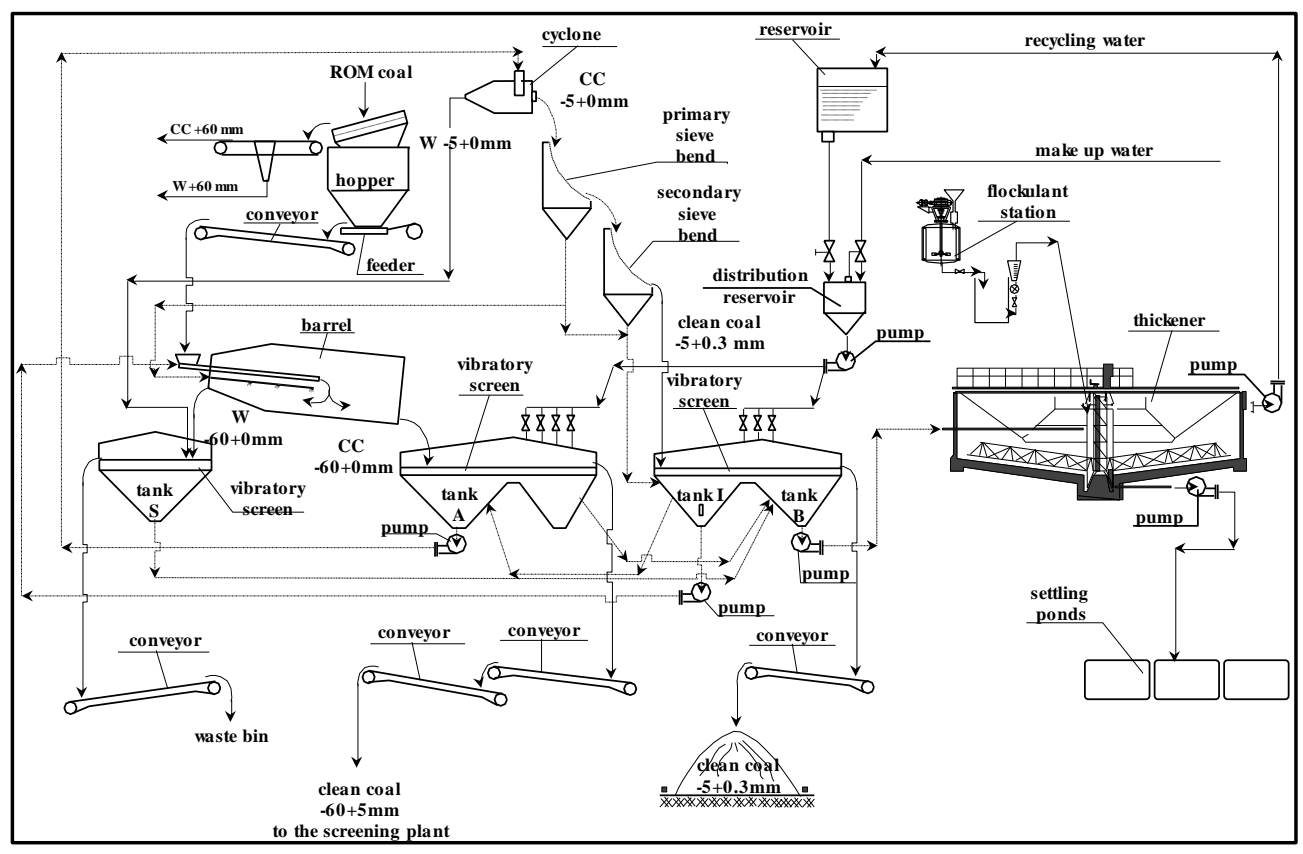

Figure 1 Flowsheet of coal cleaning in autogeneous suspension in Parnaby plant

\section{SURFACE MINING AND PREPARATION OF COALS IN SERBIA}

Surface mining is carried out as part of a Public Enterprise Electric power industry of Serbia - JP EPS. As of July 1, 2015, EPS operates with three legal entities: parent company Elektroprivreda Srbije, dependent company Operator distribution system EPS Distribution and the subsidiary EPS Supply. JP EPS is vertical an organized company, which has founding rights in two subsidiary companies and three public companies in Kosovo and Metohija. Since June 1999, EPS has been unable to manage its capacity at Kosovo and Metohija (EPS, 2015).

JP EPS employ about 34.000 employees.

Mining operation is done in mining basin Kolubara and Kostalac. Kolubara surface mines produce about $75 \%$ of lignite in Serbia and supply three thermal power plants: Kolubara, Nikola Tesla and Morava. Kostolac surface mines produce about 25\% of lignite in Serbia and supply thermal power plant Kostolac. The maximum annual coal production in EPS was reached in 2011 and it amounted to 40.3 million tons of coal. The average annual production is within the range of 37 to 40 million tons of coal with the average calorific value of $7.500 \mathrm{~kJ} / \mathrm{kg}$. In the future production will increase in accordance with building of new thermal power plants Kostolac B3 and Kolubara B. 
Coal produced in the Mine Basin Kolubara provides the generation of about $53 \%$ of electricity in EPS, and coal from Kostolac mine provides additional 17\% of generation. TPP Morava uses coal mix from Kolubara and JP PEU Resavica.

The installed capacity of EPS's power plants amount to a total of $8.359 \mathrm{MW}$, of which in lignite-fired thermal power plants 5.171 MW. The power plants operated by EPS produced $35.855 \mathrm{GWh}$ of electricity, of which $61.8 \%$ thermal power plants produce electricity using lignite.

Total capacity of eight PE EPS TPPs, with 25 operating units, is $5.171 \mathrm{MW}$. TPPs Nikola Tesla A and B have a capacity of $2.787 \mathrm{MW}$ and annual generation of $17.889 \mathrm{GWh}$, which makes $50 \%$ of EPS electricity generation. TPP Nikola Tesla is the top electricity producer in the SEE. It has 14 units with total installed capacity of $3.288 \mathrm{MW}$, which represents one third of total installed capacities of Electric Power Industry of Serbia. TENT annual generation is higher than $50 \%$ of electricity generation in Serbia. The largest units, B1 and B2 with available capacity of $580 \mathrm{MW}$ each, are in TPP Nikola Tesla B.

TPPs Kostolac A and B have capacity of $921 \mathrm{MW}$ and annual generation of $5.989 \mathrm{GWh}$, which makes $17 \%$ of EPS electricity generation. Generation in TPPs Kolubara, Morava and Panonske CHPs was 1.183 GWh, which makes 3\% of EPS electricity generation. Maximum annual generation of power plants operated by EPS, as from 1990, was achieved in 2013 and amounted to $37.433 \mathrm{GWh}$ of electricity.

Lignite produced in thermal power plants has lower calorific value and it is processed in facilities with large capacity. The main purpose of lignite preparation is reduced the coal to $100 \%-40 \mathrm{~mm}$, which require processes in thermal power plants. The largest amounts of produced coal are used for combustion in thermal power plants and much less in commercial purpose.

The average of 29 to 31 million tons of coal is produced in the Mine Basin Kolubara. The average calorific value of coal used for TPP operation is $7.700 \mathrm{~kJ} / \mathrm{kg}$.

Kolubara currently supplies thermal power plant Nikola Tesla A (total capacity 1640 MW), thermal power plant Nikola Tesla B (total capacity $1236 \mathrm{MW}$ ), thermal power plant Kolubara A (total capacity $245 \mathrm{MW}$ ) and one heating plant. It near future Kolubara will supply coal new power plant Kolubara B (total capacity $350 \mathrm{MW}$ ).

Coal preparation in Kolubara is performed in three plants: the crushing plant Tamnava, dry separation plant in Vreoci and wet separation plant in Vreoci.

PK Tamnava crushing plant, with capacity of $1250 \mathrm{t} / \mathrm{h}$ processes 12 million tones of coal annualy. Coal is crushed in one stage from $600 \mathrm{~mm}$ to $30 \mathrm{~mm}$ and transported to thermal power plants Nikola Tesla A and Nikola Tesla B. When necessary for customer demands in commercial uses, coal is screened on rollen rost to obtain $-600+80 \mathrm{~mm}$ clean coal. On 
PK Tamnava it is planned to increase the coal production to 17 million t/y. New production facilities will supply new thermal power plant Kolubara B.

At the crushing plant Tamnava, there is a second phase of construction where conveyor for coal and the third crushing line are mounted. In addition, the fourth line of crushing is mounted, where coal will be crushed in two-stages in sizers and than it will be deposed on new storage pond for fine coal. At new storage pond homogenization of fine coal, size class $-30+0 \mathrm{~mm}$, will be performed.

The dry separation plant in Vreoci have a total capacity of $4000 \mathrm{t} / \mathrm{h}$ and processes 16 million tons of coal annualy for thermal power plants Nikola Tesla A, Nikola Tesla B and Kolubara. Preparation of coal is performed by crushing (in roll or hammer crushers) and screening on screens (with openings of $30 \mathrm{~mm}, 120$ or $150 \mathrm{~mm}$ ). Coal is reduced from $400 \mathrm{~mm}$ to $100 \%-30 \mathrm{~mm}$ and sent to thermal power plants. When necessary, for commercial users, $-400+150(120) \mathrm{mm}$ clean coal is produced.

Technological process of lignite preparation in wet separation plant and drying Kolubara in Vreoci consists of the following: the run-of-mine coal from open pits is crushed and screened. Clean coal, size class $-30(38)+0 \mathrm{~mm}$, is transported to thermal power plant Kolubara A, and coal, size class $-150+30(38) \mathrm{mm}$, is conveyed to wet cleaning plant in Vreoci. Coal cleaning equipment is done in Drew-boy concentrator (in suspension of quartz sand at density of $\left.1.30 \mathrm{~kg} / \mathrm{dm}^{3}\right)$. Cleaned coal which has passed over the washing and drain screens is transfer to drying plant, with capacity of $845.000 \mathrm{t} / \mathrm{y}$ (Kostović, 2014).

The quality of raw coal and washing coal are presented on Table 3 (Kostović, 2011).

Table 3 The quality of raw coal and washing coal in Kolubara preparation plant

\begin{tabular}{|l|c|c|c|c|c|}
\hline \multicolumn{1}{|c|}{ Mine } & $\begin{array}{c}\text { Mass, } \\
\mathrm{t}\end{array}$ & $\begin{array}{c}\text { Moisture, } \\
\%\end{array}$ & $\begin{array}{c}\text { Ash, } \\
\%\end{array}$ & $\begin{array}{c}\text { Ash }_{\text {w.m., }} \\
\%\end{array}$ & $\begin{array}{c}\text { L.C.V. } \\
\text { GJ/t }\end{array}$ \\
\hline Raw coal & 928149 & 50.9 & 12.1 & 24.64 & 7.95 \\
\hline $\begin{array}{l}\text { Washing coal } \\
150+30 \mathrm{~mm}\end{array}$ & 844714 & 54.2 & 6.5 & 14.19 & 8.65 \\
\hline Drying coal & 526545 & 26.5 & 7.8 & 10.61 & 16.88 \\
\hline
\end{tabular}

The coal is dried by Fleissner process in 4 groups of autoclaves. After drying, clean coal is screened on two double-deck vibrating screens and five final products are obtained: $150+60 \mathrm{~mm},-60+30 \mathrm{~mm},-30+15 \mathrm{~mm},-15+5 \mathrm{~mm}$ and $-5+0 \mathrm{~mm}$. In the drying process enters coal containing on average $54.2 \%$ moisture, $6.5 \%$ ash, $14.19 \%$ ash (without moisture) and lower calorific value of $8.65 \mathrm{GJ} / \mathrm{t}$. Clean coal products, i.e. different size classes, contain on average (minimum and maximum values): 26-29.1\% moisture, 7.1$11.5 \%$ ash, 9.6-16.22\% ash (without moisture) and low calorific value (L.C.V.) 15.17$17.23 \mathrm{GJ} / \mathrm{t}$. 
Kostolac Mine Basin is produced the average of 9 million tons of coal. Thermal power plants Kostolac A (total capacity $310 \mathrm{MW}$ ) and Kostolac B (total capacity $692 \mathrm{MW}$ ) are suupplied from Kostolac Mine Basin. The average calorific value of coal used for TPP operation is $8.300 \mathrm{~kJ} / \mathrm{kg}$. Also, the plan is to increase the capacity of the mine to 12 million t/y of coal for supplying new thermal power plant Kostolac B3.

Run-of-mine coal, size class $-600+0 \mathrm{~mm}$, from open pit Drmno is transported by belt conveyer to the crushing plants. Coal is crushed in one stage in hammer crushers to 100\%-40 mm. The capacity of crushing plants in thermal power plants Kostolac A and Kostolac B are 2.5 million t/y, respectively 6 million t/y. Small amounts of coal are produced for commercial uses.

\section{UNDERWATER MINING AND PREPARATION OF COALS IN SERBIA}

Underwater mining and preparation of coals in Serbia has been done in Kovin coal mine. Kovin coal mine is located on Danube. Operation started in 1990 at the projecting capacity of $300.000 \mathrm{t} / \mathrm{y}$, but capacity was decreased to $150.000 \mathrm{t} / \mathrm{y}$ in whole operating period. Coal, mined with waterway wheel excavator, hydraulically suctioned and transported using centrifugal pumps to four-deck vibratory screen with openings of 60 $\mathrm{mm}, 30 \mathrm{~mm}, 15 \mathrm{~mm}$ and $5 \mathrm{~mm}$ for production appropriate size classes as final products. Fine coal, size class $-10(8)+0 \mathrm{~mm}$, are sent to the setling pond. From setling pond coal is escavated and sent to modular facilities with capacity of $40 \mathrm{t} / \mathrm{h}$. In modular facilities coal is cleaned in autogeneous suspension in dense medium cyclones. In past suspension of magnetite was used as heavy media.

\section{CONCLUSION}

In Serbia, more than 40 million tones of coal are produced per year, mostly lignite of lower calorific value, which is combusted in thermal power plants. Production of coal in Serbia doesn't satisfy a need for commercial users (domestic, industrial), so there is need for extra 1.5 million tons of coal. The production of electricity in lignite-power plant is dominating in total production of electricity. Considering this and also taking the reserves of coal into consideration, it can be said for sure that coal will be a significant fuel and base of the future energetic development in Serbia. 


\section{REFERENCES}

IVKOVIĆ, M. (2012) Sistematizacija prirodno-geoloških uslova eksplaoatacije uglja u podzemnim rudnicima u Srbiji. Komitet za podzemnu eksploataciju, Resavica,

KOSTOVIĆ, N. (2011) Priprema uglja u Srbiji, Monografija: Stanje i perspektive pripreme mineralnih sirovina u Srbiji. Inženjerska akademija Srbije, Beograd, pp. 61-72

KOSTOVIĆ MILENA (2014) Priprema uglja, Monografija: Srpsko rudarstvo i geologija u drugoj polovini XX veka. Rudarski institut Beograd, str. 495-513.

NIKOLI, P., DIMITRIJEVIĆ, D. (1990) Ugalj Jugoslavije. Pronalazaštvo, Beograd.

VULETIĆ, V. (2004) Ugalj: Karakteristike, priprema, korišćenje. GENEKS, NIS Energogas, Udrženje za gas Cavagna Group S.p.A. -Brescia, Beograd, 2004.

EPS (2016) Production Capacities. [Online] Available from: http://eps.rs/en/Poslovanjeugalj/Pages/Kapaciteti-ugalj.aspx

JPPEU (2017) JPPEU. [Online] Available from: http://www.jppeu.rs/index.html 